\title{
Sistem Pendukung Keputusan Pemilihan Pelatih Ekstrakurikuler Bulutangkis Pada Sekolah Menengah Kejuruan Pembangunan Jaya-Yakapi
}

\author{
Shintia Maharani ${ }^{1}$, Ahmad Ishaq ${ }^{2}$, Ahmad Al Kaafi ${ }^{3}$ \\ ${ }^{1}$ STMIK Nusa Mandiri \\ e-mail: shintiamaharani07.sm@gmail.com \\ ${ }^{2}$ Universitas Bina Sarana Informatika \\ e-mail: ishaq@bsi.ac.id \\ ${ }^{3}$ Universitas Bina Sarana Informatika \\ e-mail: ahmad.akf@bsi.ac.id
}

\begin{abstract}
Cara Sitasi: Maharani, S., Ishaq, A., \& Kaafi, A. A. (2019). Sistem Pendukung Keputusan Pemilihan Pelatih Ekstrakurikuler Bulutangkis Pada Sekolah Menengah Kejuruan Pembangunan Jaya-Yakapi. Paradigma - Jurnal Komputer dan Informatika, 21(2), 179-186. doi:10.31294/p.v21i2.6342
\end{abstract}

\begin{abstract}
Extracurricular is an internal learning process to meet student needs. Extracurricular activities outside the school that aim to develop and channel the potential that exists in students. The system is a collection of subsystems (elements) that correlate with each other to achieve certain goals. Decision support systems can be interpreted as a system designed that is used to support management in decision making. The AHP method used is a method that is easy to understand and easy to learn by people who will use it. AHP method is structured decision making. The method includes the criteria assessment process that starts from weighting criteria to be able to know the importance of each criterion, then criteria that can produce alternatives to find out the highest weight of each alternative. The application of the AHP method resulted in good decisions in the completion and calculation of the criteria values possessed by badminton extracurricular trainers, so that accurate results were known in the process of selecting badminton extracurricular trainers. The application of the AHP method by using Microsoft Excel can facilitate the principal of the SMK Pembangunan Jaya-Yakapi in determining badminton extracurricular trainers.
\end{abstract}

Keywords: Extracurricular, Decision Support System, AHP Method

\section{PENDAHULUAN}

Ekstrakurikuler merupakan sebuah internal dari suatu proses belajar untuk memenuhi kebutuhan siswa. Ektrakurikuler merupakan kegiatan di luar sekolah yang bertujuan untuk mengembangkan dan menyalurkan potensi yang ada dalam diri siswa (Karno \& Wicaksono, 2016). Dalam ekstrakurikuler pelatih merupakan hal yang sangat penting. Pelatih dapat menentukan suatu keberhasilan bagi anggota ekstrakurikuler bulutangkis. Untuk itu pelatih harus dapat diisi dengan seseorang yang mengetahui dasardasar dalam bulutangkis. Pemilihan berkualitas dan terbaik diperlukan agar ada prestasi berikutnya.

Dari hasil penelitian yang dilakukan, proses pemilihan pelatih ekstrakurikuler bulutangkis di SMK Pembangunan Jaya-YAKAPI hanya ditentukan dengan satu kriteria tanpa melihat adanya kriteria yang lainnya, padahal dari semua kriteria ada yang nilainya sangat penting dan beberapa kriteria yang kurang penting dalam pemilihan pelatih ekstrakurikuler bulutangkis. Sehingga dapat menyebabkan sulitnya menentukan pelatih terbaik, serta tidak ada sistem yang dapat mendukung penggunaan bobot untuk mendapatkan hasil yang tepat (Misie, Aksad, \& Fathimah, 2015).

Oleh karena itu penulis ingin membuat sistem pendukung keputusan sesuai dengan kriteria yang ditetapkan. Metode AHP (Analitycal Hierarchy Process) yang penulis gunakan merupakan metode yang mudah dimengerti dan mudah dipelajari oleh orang yang akan menggunakannya. Metode Analitycal Hierarchy Process (AHP) merupakan pengambilan keputusan yang terstruktur. Metode tersebut meliputi proses penilaian kriteria yang dimulai dari pembobotan kriteria untuk dapat mengetahui kepentingan masing-masing kriteria, kemudian kriteria yang dapat menghasilkan alternatif untuk mengetahui bobot tertinggi dari setiap alternatif yang ada 
(Saefudin \& Wahyuningsih, 2014). Diharapkan penulis dapat membantu kepala sekolah SMK Pembangunan Jaya - YAKAPI dalam mengambil keputusan pemilihan pelatih ekstrakurikuler bulutangkis.

\section{METODOLOGI PENELITIAN}

Tahapan Penelitian

Sebagai langkah-langkah dalam penyusunan penelitian yang dilakukan adalah sebagai berikut :

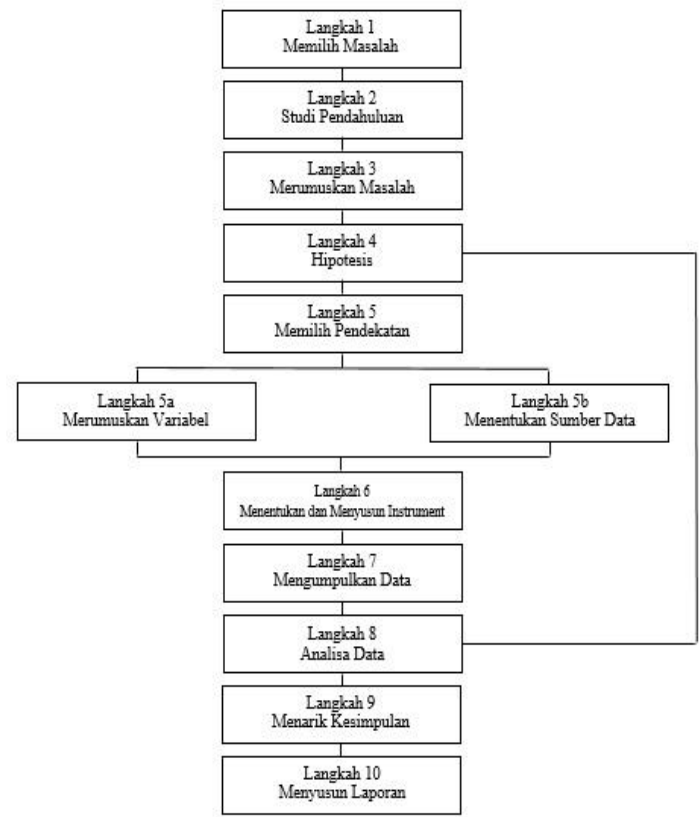

Sumber : Data Penelitian (2019)

\section{Gambar 1 Tahapan Penelitian}

Setelah data-data yang penulis perlukan terkumpul, maka langkah selanjutnya adalah menganalisis data. Analisis data yang penulis gunakan pada penelitian ini menggunakan analisis kuantitatif. Analisis dimana peneliti melakukan pengujian dari hipotesa dengan teknik-teknik statistik. Data statistik tersebut didapatkan dari kuesioner dengan menggunakan metode pendekatan Analytical Hierarchy Process (AHP) (Paramita, Mustika, \& Farkhatin, 2017).

Menurut (Diana, 2018) Langkah-langkah yang diberikan pada metode AHP adalah sebagai berikut :

\section{A. Mendefinisikan Masalah Dan Menetukan \\ Solusi Yang Diinginkan}

Permasalahan yang pada awalnya tidak terstruktur, pada tahap ini kita pecahkan secara jelas, detail dan mudah dipahami. Selanjutnya kita menentukan beberapa solusi yang mungkin diambil untuk menyelesaikan permasalahn yang ada. Dari sekian banyak solusi yang ada kita coba menentukan solusi yang cocok bagi masalah tersebut. Solusi inilah yang akan dikembangkan lebih lanjut dalam tahap berikutnya.

\section{B. Membuat Struktur Hirarki}

Struktur hirarki ini merupakan sistesa dari pemikiran alamiah manusia yang terbiasa untuk mengelompokkan seseuatu berdasarkan tingkatnya. Ada 3 hal penting dalam struktur hirarki yaitu : tujuan, kriteria dan alternatif. Tujuan merupakan struktur hirarki yang paling atas disusul dengan kriteria dan kemudian alternatif penyelesaian masalah. Bentuk hirarki ini sangat berkaitan dengan kompleksitas permasalahan. Pada beberapa kasus, hirarki dilanjutkan dengan sub kriteria (jika mungkin diperlukan).

C. Membuat Matriks Perbandingan Berpasangan Perbandingan berpasangan dilakukan berdasarkan judgment pengambil keputusan dengan menilai tingkat kepentingan suatu elemen dibandingkan elemen lain. Pada tahap menyusun perbandingan berpasangan kita akan membandingkan semua sub sistem hirarki yang telah kita buat dalam bentuk perbandingan berpasangan. Perbandingan ini ditransformasi ke dalam bentuk matriks agar bisa dilakukan proses perhitungan numerik. Proses perbandingan berpasangan ini dilakukan dari tingkatan paling atas dilanjutkan ke tingkatan berikutnya.

D. Menghitung Vektor eigen normalisasi

Perhitungan nilai vector eigen normalisasi ini dilakukan untuk semua perbandingan berpasangan. Nilai ini merupakan bobot setiap elemen untuk penentuan prioritas elemen-elemen dari setiap matriks perbandingan berpasangan.

E. Memeriksa konsistensi hirarki

Konsistensi perlu diukur untuk mengetahui apakah konsistensi antara objek yang dinilai adalah benar. Objek yag dimaksud adalah data penilaian pengambil keputusan yang diisikan pada matriks perbandingan berpasangan. Rasio konsistensi ini diukur indek konsistensi dibagi dengan indeks random yang berdasarkan pada ukuran matriks. Konsistensi yang diharapkan adalah konsistensi yang mendekati sempurna agar menghasilkan keputusan yang mendekati valid.

F. Melakukan perhitunagan akhir untuk masingmasing alternatif dengan menjumlahkan hasil perkalian nilai eigen vektor normalisasi masingmasing kriteria dengan nilai eigen vektor masingmasing alternatif.

\section{HASIL DAN PEMBAHASAN}

\section{Struktur Analytical Hierarchy Process}

Dalam hierarki keputusan terdapat objek yang akan dibahas yaitu tujuan, kriteria dan alternatif. Berikut ini adalah gambar dari struktur hierarki keputusan yang digunakan dalam skripsi ini. 


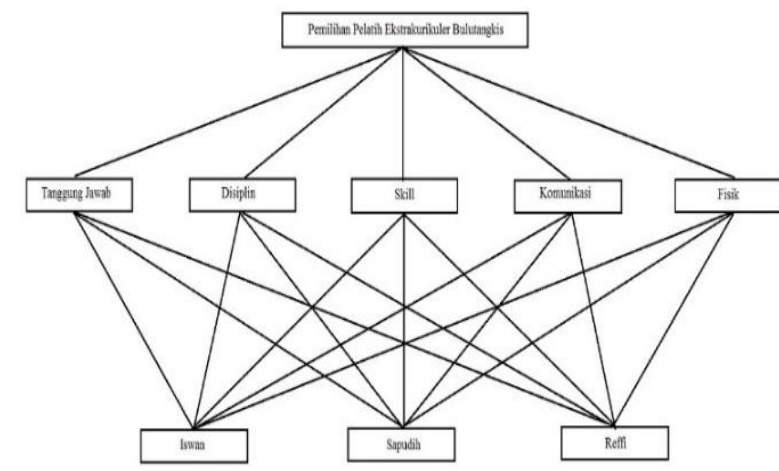

Sumber : Data Penelitian (2019)

Gambar 2 Hierarki Pemilihan Pelatih

Ekstrakurikuler Bulutangkis

\section{Perbandingan Berpasangan Kriteria dan} Alternatif

1. Data Perbandingan Kriteria dan Altenatif

Setelah menentukan kriteria, dilakukan pemberian bobot pada hubungan antar kriteria dengan kriteria. Penilaian dilakukan oleh 6 responden dari Kepala Sekolah, Guru, dan Anggota Ekstrakurikuler dengan cara pengisian kuesioner sehingga menghasilkan data mentah yang dapat dilihat pada lampiran. Berikut ini adalah hasil kuesioner data mentah yang sudah diterjemahkan dalam bentuk tabel perbandingan berpasangan

\begin{tabular}{|c|c|c|c|c|c|}
\hline Kriteria & $\begin{array}{c}\text { Tanggung } \\
\text { Jawab }\end{array}$ & Disiplin & Keterampilan & Komunikasi & Fisik \\
\hline $\begin{array}{c}\text { Tanggung } \\
\text { Jawab }\end{array}$ & 1 & 3 & 5 & 7 & 5 \\
\hline Disiplin & 0,33 & 1 & 7 & 5 & 5 \\
\hline Keterampilan & 0,20 & 0,14 & 1 & 3 & 5 \\
\hline Komunikasi & 0,14 & 0,20 & 0,33 & 1 & 3 \\
\hline Fisik & 0,20 & 0,20 & 0,20 & 0,33 & 1 \\
\hline
\end{tabular}

dengan menggunakan aplikasi Microsoft Excel.

Tabel 1 Perbandingan Berpasangan Antar Kriteria (Responden 1)

Sumber : Data Penelitian (2019)

Tabel 2 Perbandingan Berpasangan Antar Kriteria (Responden 2)

\begin{tabular}{|l|c|c|c|c|c|}
\hline \multicolumn{1}{|c|}{ Kriteria } & $\begin{array}{c}\text { Tanggung } \\
\text { Jawab }\end{array}$ & Disiplin & Keterampilan & Komunikasi & Fisik \\
\hline $\begin{array}{l}\text { Tanggung } \\
\text { Jawab }\end{array}$ & 1 & 3 & 5 & 3 & 9 \\
\hline Disiplin & 0,33 & 1 & 3 & 5 & 7 \\
\hline Keterampilan & 0,20 & 0,33 & 1 & 3 & 3 \\
\hline Komunikasi & 0,33 & 0,20 & 0,33 & 1 & 5 \\
\hline Fisik & 0,11 & 0,14 & 0,33 & 0,20 & 1 \\
\hline
\end{tabular}

Sumber : Data Penelitian (2019)

Tabel 3 Perbandingan Berpasangan Antar Kriteria (Responden 3)

\begin{tabular}{|l|c|c|c|c|c|}
\hline \multicolumn{1}{|c|}{ Kriteria } & $\begin{array}{c}\text { Tanggung } \\
\text { Jawab }\end{array}$ & Disiplin & Keterampilan & Komunikasi & Fisik \\
\hline $\begin{array}{l}\text { Tanggung } \\
\text { Jawab }\end{array}$ & 1 & 3 & 5 & 7 & 9 \\
\hline Disiplin & 0,33 & 1 & 7 & 5 & 7 \\
\hline Keterampilan & 0,20 & 0,14 & 1 & 3 & 5 \\
\hline Komunikasi & 0,14 & 0,20 & 0,33 & 1 & 3 \\
\hline Fisik & 0,11 & 0,14 & 0,20 & 0,33 & 1 \\
\hline
\end{tabular}

Sumber : Data Penelitian (2019)
Tabel 4 Perbandingan Berpasangan Antar Kriteria (Responden 4)

\begin{tabular}{|l|c|c|c|c|c|}
\hline \multicolumn{1}{|c|}{ Kriteria } & $\begin{array}{c}\text { Tanggung } \\
\text { Jawab }\end{array}$ & Disiplin & Keterampilan & Komunikasi & Fisik \\
\hline $\begin{array}{l}\text { Tanggung } \\
\text { Jawab }\end{array}$ & 1 & 3 & 7 & 5 & 9 \\
\hline Disiplin & 0,33 & 1 & 3 & 5 & 7 \\
\hline Keterampilan & 0,14 & 0,33 & 1 & 3 & 3 \\
\hline Komunikasi & 0,20 & 0,20 & 0,33 & 1 & 5 \\
\hline Fisik & 0,11 & 0,14 & 0,33 & 0,20 & 1 \\
\hline
\end{tabular}

Sumber : Data Penelitian (2019)

Tabel 5 Perbandingan Berpasangan Antar Kriteria (Responden 5)

\begin{tabular}{|l|c|c|c|c|c|}
\hline \multicolumn{1}{|c|}{ Kriteria } & $\begin{array}{c}\text { Tanggung } \\
\text { Jawab }\end{array}$ & Disiplin & Keterampilan & Komunikasi & Fisik \\
\hline $\begin{array}{l}\text { Tanggung } \\
\text { Jawab }\end{array}$ & 1 & 5 & 3 & 9 & 7 \\
\hline Disiplin & 0,20 & 1 & 5 & 7 & 3 \\
\hline Keterampilan & 0,33 & 0,20 & 1 & 3 & 5 \\
\hline Komunikasi & 0,11 & 0,14 & 0,33 & 1 & 3 \\
\hline Fisik & 0,14 & 0,33 & 0,20 & 0,33 & 1 \\
\hline
\end{tabular}

Sumber : Data Penelitian (2019)

Tabel 6 Perbandingan Berpasangan Antar Kriteria (Responden 6)

\begin{tabular}{|l|c|c|c|c|c|}
\hline \multicolumn{1}{|c|}{ Kriteria } & $\begin{array}{c}\text { Tanggung } \\
\text { Jawab }\end{array}$ & Disiplin & Keterampilan & Komunikasi & Fisik \\
\hline $\begin{array}{l}\text { Tanggung } \\
\text { Jawab }\end{array}$ & 1 & 5 & 7 & 7 & 9 \\
\hline Disiplin & 0,20 & 1 & 7 & 5 & 7 \\
\hline Keterampilan & 0,14 & 0,14 & 1 & 3 & 3 \\
\hline Komunikasi & 0,14 & 0,20 & 0,33 & 1 & 5 \\
\hline Fisik & 0,11 & 0,14 & 0,33 & 0,20 & 1 \\
\hline
\end{tabular}

Sumber : Data Penelitian (2019)

Tabel 7 Perbandingan Berpasangan Antar Kriteria (Responden 7)

\begin{tabular}{|l|c|c|c|c|c|}
\hline \multicolumn{1}{|c|}{ Kriteria } & $\begin{array}{c}\text { Tanggung } \\
\text { Jawab }\end{array}$ & Disiplin & Keterampilan & Komunikasi & Fisik \\
\hline $\begin{array}{l}\text { Tanggung } \\
\text { Jawab }\end{array}$ & 1 & 3 & 5 & 3 & 9 \\
\hline Disiplin & 0,33 & 1 & 5 & 7 & 3 \\
\hline Keterampilan & 0,20 & 0,20 & 1 & 3 & 5 \\
\hline Komunikasi & 0,33 & 0,14 & 0,33 & 1 & 3 \\
\hline Fisik & 0,11 & 0,33 & 0,20 & 0,33 & 1 \\
\hline
\end{tabular}

Sumber : Data Penelitian (2019)

Tabel 8 Perbandingan Berpasangan Antar Kriteria (Responden 8)

\begin{tabular}{|l|c|c|c|c|c|}
\hline \multicolumn{1}{|c|}{ Kriteria } & $\begin{array}{c}\text { Tanggung } \\
\text { Jawab }\end{array}$ & Disiplin & Keterampilan & Komunikasi & Fisik \\
\hline $\begin{array}{l}\text { Tanggung } \\
\text { Jawab }\end{array}$ & 1 & 5 & 3 & 9 & 7 \\
\hline Disiplin & 0,20 & 1 & 5 & 3 & 5 \\
\hline Keterampilan & 0,33 & 0,20 & 1 & 3 & 7 \\
\hline Komunikasi & 0,11 & 0,33 & 0,33 & 1 & 5 \\
\hline Fisik & 0,14 & 0,20 & 0,14 & 0,20 & 1 \\
\hline
\end{tabular}

Sumber : Data Penelitian (2019)

Tabel 9 Perbandingan Berpasangan Antar Kriteria (Responden 9)

\begin{tabular}{|l|c|c|c|c|c|}
\hline \multicolumn{1}{|c|}{ Kriteria } & $\begin{array}{c}\text { Tanggung } \\
\text { Jawab }\end{array}$ & Disiplin & Keterampilan & Komunikasi & Fisik \\
\hline $\begin{array}{l}\text { Tanggung } \\
\text { Jawab }\end{array}$ & 1 & 3 & 3 & 9 & 7 \\
\hline Disiplin & 0,33 & 1 & 5 & 5 & 3 \\
\hline Keterampilan & 0,33 & 0,20 & 1 & 5 & 7 \\
\hline Komunikasi & 0,11 & 0,20 & 0,20 & 1 & 3 \\
\hline Fisik & 0,14 & 0,33 & 0,14 & 0,33 & 1 \\
\hline
\end{tabular}

Sumber : Data Penelitian (2019) 
Tabel 10 Perbandingan Berpasangan Antar Kriteria (Responden 10)

\begin{tabular}{|l|c|c|c|c|c|}
\hline \multicolumn{1}{|c|}{ Kriteria } & $\begin{array}{c}\text { Tanggung } \\
\text { Jawab }\end{array}$ & Disiplin & Keterampilan & Komunikasi & Fisik \\
\hline $\begin{array}{l}\text { Tanggung } \\
\text { Jawab }\end{array}$ & 1 & 3 & 7 & 9 & 5 \\
\hline Disiplin & 0,33 & 1 & 5 & 7 & 3 \\
\hline Keterampilan & 0,14 & 0,20 & 1 & 5 & 5 \\
\hline Komunikasi & 0,11 & 0,14 & 0,20 & 1 & 3 \\
\hline Fisik & 0,20 & 0,33 & 0,20 & 0,33 & 1 \\
\hline
\end{tabular}

Sumber : Data Penelitian (2019)

Setiap perbandingan kriteria yang sama pada hasil kesepuluh Pairwise Comparison antara kriteria pada tabel 1 sampai dengan 10 akan dihitung ratarata geometriknya dengan menggunakan rumus:

$\mathrm{G}=\sqrt[\mathrm{n}]{\mathrm{x}_{1} \mathrm{x}_{2} \ldots \mathrm{x}_{\mathrm{n}}}$

Keterangan:

$\mathrm{x}=$ hasil perbandingan berpasangan kriteria

$\mathrm{n}=$ jumlah total responden

Didalam pengecekan konsistensi data ini, digunakan rasio konsistensi yang dihasilkan harus kurang dari $10 \%$, dimana nilai CR harus kurang dari 0,1 . Berikut ini tabel jumlah dari perbandingan berpasangan antar kriteria :

Tabel 11 Perbandingan Berpasangan Antar Kriteria (Combined)

\begin{tabular}{|c|c|c|c|c|c|}
\hline Kriteria & $\begin{array}{c}\text { Tanggung } \\
\text { Jawab }\end{array}$ & Disiplin & Keterampilan & Komunikasi & Fisik \\
\hline $\begin{array}{c}\text { Tanggung } \\
\text { Jawab }\end{array}$ & 1 & 3,4968 & 4,7452 & 6,3175 & 7,4207 \\
\hline Disiplin & 0,2860 & 1 & 4,9939 & 5,2556 & 4,6632 \\
\hline Keterampilan & 0,2107 & 0,2002 & 1 & 3,3227 & 4,5882 \\
\hline Komunikasi & 0,1583 & 0,1903 & 0,3010 & 1 & 3,6801 \\
\hline Fisik & 0,1348 & 0,2144 & 0,2180 & 0,2717 & 1 \\
\hline Total & $\mathbf{1 , 7 8 9 8}$ & $\mathbf{5 , 1 0 1 8}$ & $\mathbf{1 1 , 2 5 8 0}$ & $\mathbf{1 6 , 1 6 7 6}$ & $\mathbf{2 1 , 3 5 2 2}$ \\
\hline
\end{tabular}

Sumber : Data Penelitian (2019)

2. Data Perbandingan Alternatif Berdasarkan Kriteria

Setelah data perbandingan kriteria selesai diinput kedalam Microsoft Excel, langkah selanjutnya adalah menginput data perbandingan alternatif. Alternatif yang dipilih harus memenuhi kriteriakriteria sebelumnya yang sudah ditentukan. Terdapat 3 alternatif nama pelatih yang didapat dari hasil wawancara dengan Kepala Sekolah.

Tabel 12 Perbandingan rata-rata kriteria Tanggung Jawab

\begin{tabular}{|c|c|c|c|}
\hline Tanggung Jawab & Iswan & Sapudih & Reffi \\
\hline Iswan & 1 & 6,1135 & 7,2365 \\
\hline Sapudih & 0,1636 & 1 & 4,3597 \\
\hline Reffi & 0,1382 & 0,2294 & 1 \\
\hline Total & 1,3018 & 7,3429 & 12,5962 \\
\hline
\end{tabular}

Sumber : Data Penelitian (2019)
Tabel 13 Perbandingan rata-rata kriteria Disiplin

\begin{tabular}{|l|c|c|c|}
\hline Disiplin & Iswan & Sapudih & Reffi \\
\hline Iswan & 1 & 5,1210 & 6,8762 \\
\hline Sapudih & 0,1953 & 1 & 4,1426 \\
\hline Reffi & 0,1454 & 0,2414 & 1 \\
\hline Total & $\mathbf{1 , 3 4 0 7}$ & $\mathbf{6 , 3 6 2 4}$ & $\mathbf{1 2 , 0 1 8 7}$ \\
\hline
\end{tabular}

Sumber : Data Penelitian (2019)

Tabel 14 Perbandingan rata-rata kriteria Keterampilan

\begin{tabular}{|l|c|c|c|}
\hline Keterampilan & Iswan & Sapudih & Reffi \\
\hline Iswan & 1 & 6,0666 & 7,6746 \\
\hline Sapudih & 0,1648 & 1 & 4,2154 \\
\hline Reffi & 0,1303 & 0,2372 & 1 \\
\hline \multicolumn{1}{|c|}{ Total } & $\mathbf{1 , 2 9 5 1}$ & $\mathbf{7 , 3 0 3 9}$ & $\mathbf{1 2 , 8 9 0 1}$ \\
\hline
\end{tabular}

Sumber : Data Penelitian (2019)

Tabel 15 Perbandingan rata-rata kriteria Komunikasi

\begin{tabular}{|l|c|c|c|}
\hline \multicolumn{1}{|c|}{ Komunikasi } & Iswan & Sapudih & Reffi \\
\hline Iswan & 1 & 6,4339 & 7,2365 \\
\hline Sapudih & 0,1554 & 1 & 4,0055 \\
\hline Reffi & 0,1382 & 0,2497 & 1 \\
\hline \multicolumn{1}{|c|}{ Total } & $\mathbf{1 , 2 9 3 6}$ & $\mathbf{7 , 6 8 3 6}$ & $\mathbf{1 2 , 2 4 2 1}$ \\
\hline
\end{tabular}

Sumber : Data Penelitian (2019)

Tabel 16 Perbandingan rata-rata kriteria Fisik

\begin{tabular}{|l|c|c|c|}
\hline \multicolumn{1}{|c|}{ Fisik } & Iswan & Sapudih & Reffi \\
\hline Iswan & 1 & 6,6541 & 7,4842 \\
\hline Sapudih & 0,1503 & 1 & 4,2154 \\
\hline Reffi & 0,1336 & 0,2372 & 1 \\
\hline Total & $\mathbf{1 , 2 8 3 9}$ & $\mathbf{7 , 8 9 1 3}$ & $\mathbf{1 2 , 6 9 9 6}$ \\
\hline
\end{tabular}

Sumber : Data Penelitian (2019)

\section{Pembobotan Kriteria dan Alternatif}

Setelah penginputan dan perbandingan antar kriteria selesai dimasukan kedalam Microsoft Excel, akan menghasilkan normalisasi matriks antar kriteria yang akan menentukan bobot setiap kriteria.

\section{Pembobotan antar Kriteria}

\section{Tabel 17 Eigen Vektor Normalisasi Antar} Kriteria

\begin{tabular}{|c|c|c|c|c|c|c|}
\hline Kriteria & Tanggung Jawab & Disiplin & Keterampilan & Komunikasi & Fisik & Eigen Vektor \\
\hline Tanggung Jawab & 1,000 & 3,497 & 4,745 & 6,318 & 7,421 & 0,496 \\
\hline Disiplin & 0,286 & 1,000 & 4,994 & 5,256 & 4,663 & 0,307 \\
\hline Skill & 0,211 & 0,200 & 1,000 & 3,323 & 4,588 & 0,126 \\
\hline Komunikasi & 0,158 & 0,190 & 0,301 & 1,000 & 3,680 & 0,043 \\
\hline Fisik & 0,135 & 0,214 & 0,218 & 0,272 & 1,000 & 0,027 \\
\hline \multicolumn{7}{|c|}{ Jumlah } \\
\hline
\end{tabular}

Sumber : Data Penelitian (2019) 
Dalam menentukan lamda maksimal matriks perbandingan berpasangan harus dikalikan dengan eigen vektor normalisasi.

$\begin{array}{lllllllll}1,000 & 3,497 & 4,745 & 6,318 & 7,421 & & 0,496 & & 0,888 \\ 0,286 & 1,000 & 4,994 & 5,256 & 4,663 & & 0,307 & \\ 0,211 & 0,200 & 1,000 & 3,323 & 4,588 & \mathbf{X} & 0,126 \\ 0,158 & 0,190 & 0,301 & 1,000 & 3,680 & & 0,043 & \\ 0,421 \\ 0,135 & 0,214 & 0,218 & 0,272 & 1,000 & & 0,027 & & 0,701 \\ \mathbf{1 , 7 9 0} & \mathbf{5 , 1 0 2} & \mathbf{1 1 , 2 5 8} & \mathbf{1 6 , 1 6 8} & \mathbf{2 1 , 3 5 2} & & \mathbf{1 , 0 0 0} & & \mathbf{5 , 1 6 1}\end{array}$

Hasil dari perkalian sebelumnya dijumlahkan sehingga menghasilkan lamda maksimal yaitu 5,161.

Tahap kedua dari proses konsistensi adalah menguji konsistensi hirarki, sebagai berikut :

Menghitung indeks konsistensi (Consistency Index = CI) dengan rumus :

$\mathrm{CI}=\frac{\lambda \text { maks }-\mathrm{n}}{(\mathrm{n}-1)}$

Karena matriks berordo 5 atau terdiri dari 5 kriteria utama, maka nilai indeks konsistensi (CI) yang diperoleh adalah

$\mathrm{CI}=\frac{\lambda \text { maks }-\mathrm{n}}{(\mathrm{n}-1)}=\frac{5,161-5}{(5-1)}=0,0401$

Menghitung rasio konsistensi (Consistency Ratio = $\mathrm{CR})$ dengan rumus :

$\mathrm{CR}=\mathrm{CI} / \mathrm{RI}$

nilai RI untuk $\mathrm{n}=5$ adalah 1,12 . Dilihat pada Tabel VII Nilai IR (Indeks Random)

$$
\begin{aligned}
C R & =\frac{\mathrm{CR}}{\mathrm{RI}} \\
\mathrm{CR} & =\mathrm{CI} / \mathrm{RI} \\
& =0,0401 / 1,12 \longrightarrow 0,03 \text { (Konsisten) } \\
& =0,0358 \longrightarrow
\end{aligned}
$$

Keterangan : RI adalah nilai-nilai acak yang diperoleh dari tabel Random Consistency Index pada $\mathrm{n}$ tertentu.

Tabel 18 Nilai IR (Indeks Random)

\begin{tabular}{|c|c|}
\hline Ukuran Matriks (n) & Nilai IR (Indeks Random) \\
\hline 1,2 & 0.00 \\
\hline 3 & 0.58 \\
\hline 4 & 0.90 \\
\hline 5 & 1.12 \\
\hline 6 & 1.24 \\
\hline 7 & 1.32 \\
\hline 8 & 1.41 \\
\hline 9 & 1.45 \\
\hline 10 & 1.49 \\
\hline 11 & 1.51 \\
\hline 12 & 1.48 \\
\hline 13 & 1.56 \\
\hline 14 & 1.57 \\
\hline 15 & 1.59 \\
\hline
\end{tabular}

Sumber : Diana, 2018

2. Pembobotan Antar Alternatif

Tabel 19 Eigen Vektor Normalisasi Antar Alternatif

\begin{tabular}{|c|c|c|c|c|}
\hline Tanggung Jawab & Iswan & Sapudih & Reffi & Eigen Vektor \\
\hline Iswan & 1,000 & 6,114 & 7,237 & 0,759 \\
\hline Sapudih & 0,164 & 1,000 & 4,360 & 0,181 \\
\hline Reffi & 0,138 & 0,229 & 1,000 & 0,060 \\
\hline \multicolumn{4}{|c|}{ Jumlah } & $\mathbf{1 , 0 0 0}$ \\
\hline
\end{tabular}

Sumber : (Data Penelitian, 2019)
Dalam menentukan lamda maksimal matriks perbandingan berpasangan harus dikalikan dengan eigen vektor normalisasi.

$\begin{array}{llllll}1,000 & 6,114 & 7,237 & & 0,759 \\ 0,164 & 1,000 & 4,360 \\ 0,138 & 0,229 & 1,000 & \mathbf{X} & 0,181 \\ & 0,060 \\ \mathbf{1 , 3 0 2} & \mathbf{7 , 3 4 3} & \mathbf{1 2 , 5 9 6} & & \mathbf{1 , 0 0 0} & \mathbf{3} \\ & & & \mathbf{3 , 0 7 7}\end{array}$

Hasil dari perkalian sebelumnya dijumlahkan seluruhnya sehingga menghasilkan lamda maksimal yaitu 3,077

Tahap kedua dari proses konsistensi adalah menguji konsistensi hirarki, sebagai berikut :

Menghitung indeks konsistensi (Consistency Index = CI) dengan rumus :

$\mathrm{CI}=\frac{\lambda \text { maks }-\mathrm{n}}{(\mathrm{n}-1)}$

$\mathrm{CI}=\frac{\lambda \text { maks }-\mathrm{n}}{(\mathrm{n}-1)}=\frac{3,077-3}{(3-1)}=0,0384$

Menghitung rasio konsistensi (Consistency Ratio $=$ $\mathrm{CR})$ dengan rumus :

$$
\begin{aligned}
& C R=\frac{\mathrm{CR}}{\mathrm{RI}} \\
& \mathrm{CR}=\mathrm{CI} / \mathrm{RI} \\
& =0,0384 / 0,58 \\
& =0,0661 \longrightarrow 0,06 \text { (Konsisten) }
\end{aligned}
$$

Karena CR $<0.1(10 \%)$ maka preferensi pembobotan adalah konsisten.

Matriks perbandingan berpasangan level 2 berdasarkan kriteria tanggung jawab telah diisi dengan pertimbangan-pertimbangan yang konsisten dan eigen vektor yang dihasilkan dapat diandalkan.

\section{Hasil Penholahan Analytical Hierarchy Process}

Setelah pengolahan dan perhitungan data selesai dilakukan, langkah terakhir adalah memperoleh hasil seperti dibawah ini

\section{Eigen Vektor Keputusan}

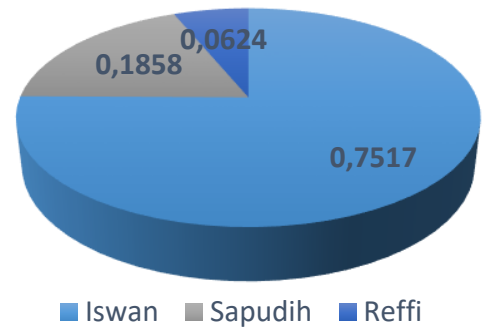

Sumber : Data Penelitian (2019)

Gambar 3 Eigen Vektor Keputusan 
Hasil pada gambar diagram diatas menunjukkan bahwa Iswan lebih unggul dari alternatif lainnya dalam pemilihan pelatih ekstrakurikuler bulutangkis dan Iswan lebih memenuhi kriteria yang telah ditentukan sebelumnya.

\section{User Interface}

A. Halaman Login

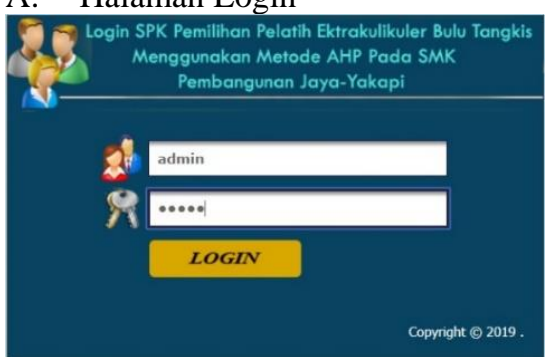

Sumber : Data Penelitian (2019)

Gambar 4 Tampilan Halaman Login

B. Halaman Home

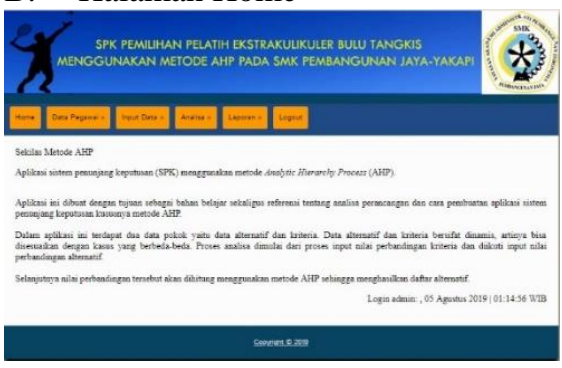

Sumber : Data Penelitian (2019)

Gambar 5 Tampilan Halaman Home

C. Menu Tambah Guru

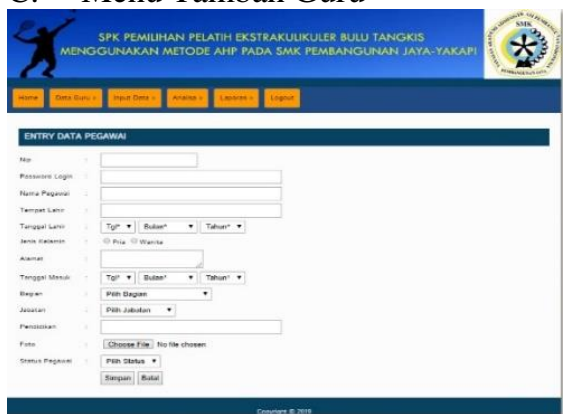

Sumber : Data Penelitian (2019)

Gambar 6 Tampilan Menu Tambah Guru

D. Menu List Data Guru

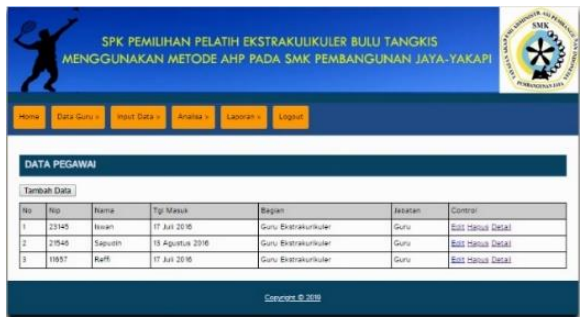

Sumber : Data Penelitian (2019)

Gambar 7 Tampilan Menu List Data Guru
E. Menu Data Bagian

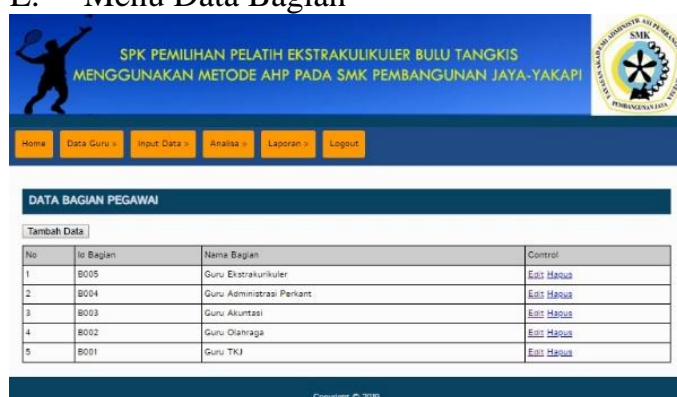

Sumber : Data Penelitian (2019)

Gambar 8 Tampilan Menu Data Bagian

F. Menu Data Jabatan

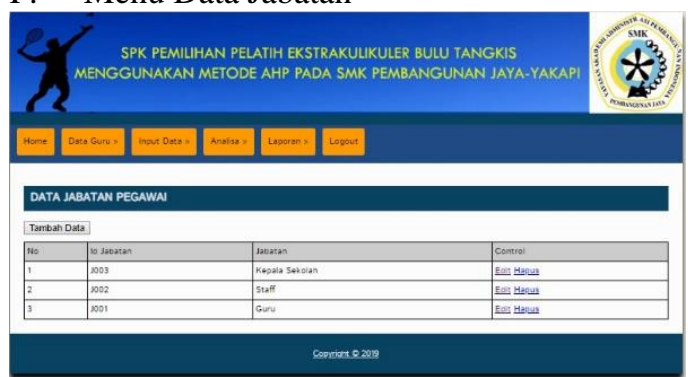

Sumber : Data Penelitian (2019)

Gambar 9 Tampilan Menu Data Jabatan

G. Input Alternatif

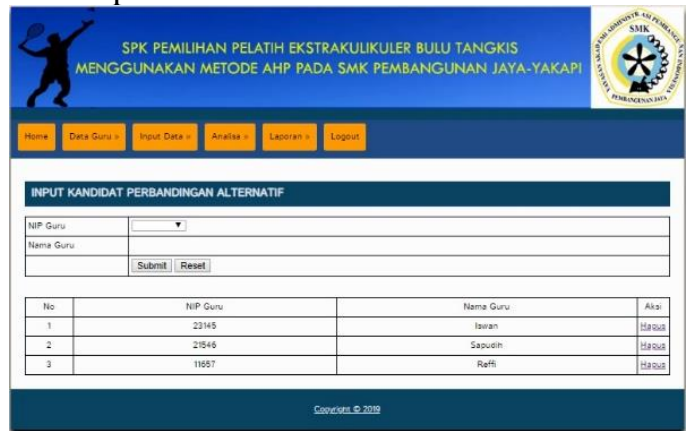

Sumber : Data Penelitian (2019)

Gambar 10 Tampilan Input Alternatif

H. Input Kriteria

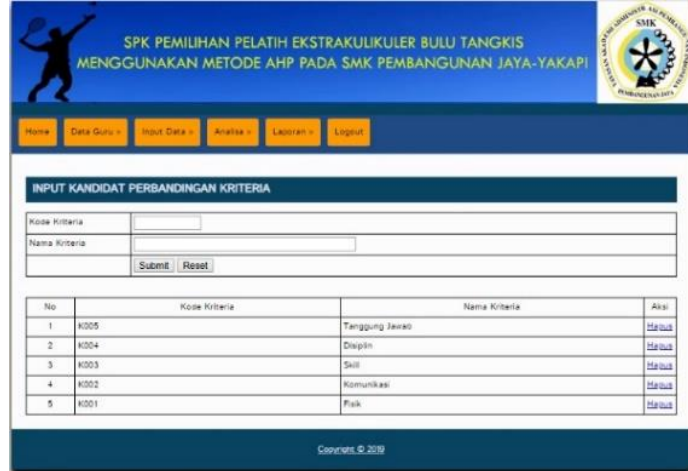

Sumber : Data Penelitian (2019)

Gambar 11 Tampilan Input Kriteria 
I. Analisa Kriteria

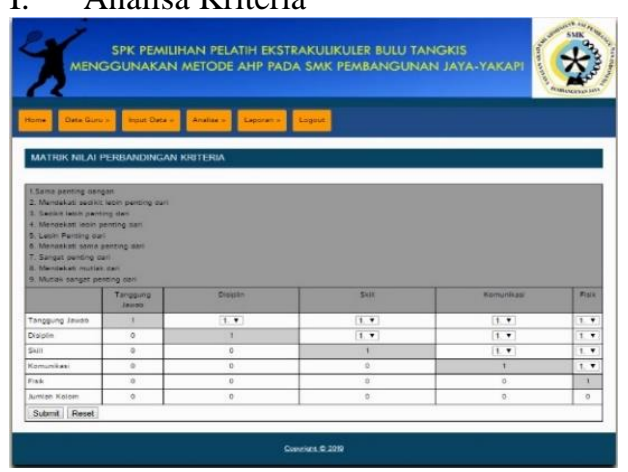

Sumber : Data Penelitian (2019)

Gambar 12 Tampilan Analisa Kriteria

J. Analisa Alternatif

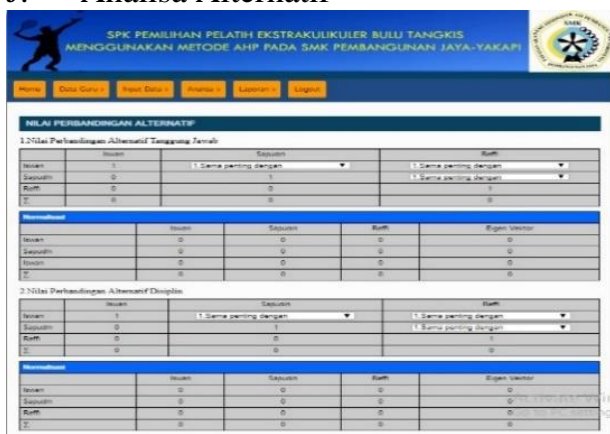

Sumber : Data Penelitian (2019)

Gambar 13 Tampilan Analisa Kriteria Tanggung Jawab dan Disiplin

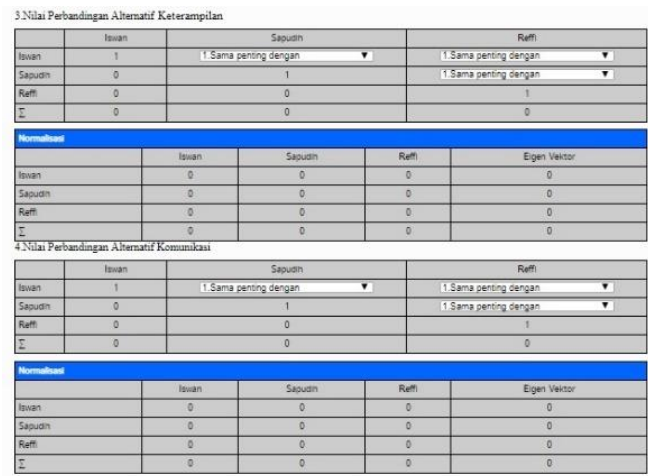

Sumber : Data Penelitian (2019)

Gambar 14 Tampilan Analisa Alternatif Keterampilan dan Komunikasi

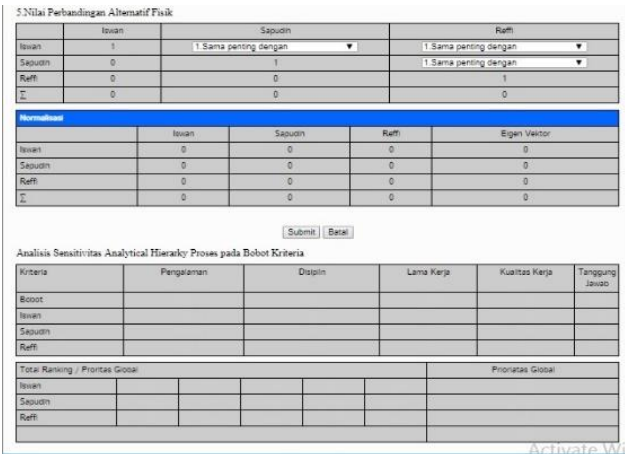

Sumber : Data Penelitian (2019)

Gambar 15 Tampilan Analisa Alternatif Fisik
K. Laporan Data Keseluruhan Guru

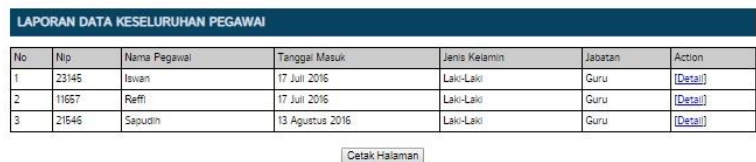

Sumber : Data Penelitian (2019)

Gambar 16 Tampilan Laporan Data Keseluruhan Guru

L. Laporan Hasil Alternatif
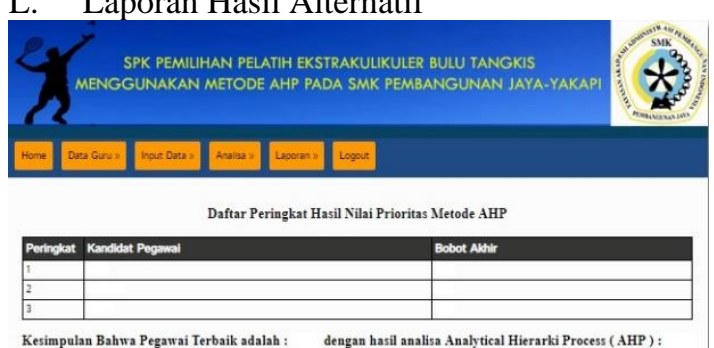

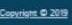

Sumber : Data Penelitian (2019)

Gambar 17 Tampilan Laporan Hasil Alternatif Kesimpulan

Dari hasil penelitian sistem pendukung keputusan pemilihan pelatih ekstrakurikuler bulutangkis pada SMK Pembangunan Jaya Yakapi dengan metode Analitycal Hierarchy Process (AHP), maka penulis menarik kesimpulan sebagai berikut :

1. Berdasarkan perhitungan Analitycal Hierarchy Process (AHP), diperoleh prioritas kriteria yang paling penting dalam penentuan pelatih ekstrakurikuler bulutangkis dimana tanggung jawab, disiplin, keterampilan, komunikasi, dan fisik menjadi prioritas bagi SMK Pembangunan Jaya-Yakapi dalam memilih pelatih ekstrakurikuler bulutangkis.

2. Dengan penerapan metode Analitycal Hierarchy Process (AHP) menghasilkan keputusan yang baik dalam penyelesaian dan perhitungan nilainilai kriteria yang dimiliki pelatih ekstrakurikuler bulutangkis, sehingga diketahui hasil yang akurat dalam proses pemilihan pelatih ekstrakurikuler bulutangkis.

3. Setelah dilakukan perhitungan dengan metode Analitycal Hierarchy Process (AHP) yang terpilih sebagai pelatih ekstrakurikuler bulutangkis dengan bobot tertinggi di SMK Pembangunan Jaya-Yakapi adalah Iswan. Data hasil perhitungan AHP diperoleh dari 10 kuesioner yang diisi oleh responden dan didapat hasil akhir bahwa Iswan lebih unggul dengan bobot 0,7517 atau $75,17 \%$. Prioritas kedua dimiliki oleh Sapudih dengan nilai bobot 0,1858 atau $18,58 \%$ dan prioritas terakhir dimiliki oleh Reffi dengan nilai bobot 0,0624 atau $6,24 \%$. 
4. Penerapan metode Analitycal Hierarchy Process dengan menggunakan Microsoft Excel dapat memudahkan kepala sekolah SMK Pembangunan Jaya-Yakapi dalam menentukan pelatih ekstrakurikuler bulutangkis.

\section{REFERENSI}

Diana. (2018). METODE DAN APLIKASI SISTEM PENDUKUNG KEPUTUSAN (I). Sleman: DEEPUBLISH (Grup Penerbitan CV BUDI UTAMA).

Karno, H. W., \& Wicaksono, T. A. (2016). Ekstrakurikuler Menggunakan Visual. 2(1), 50-56.

Misie, F. N., Aksad, H., \& Fathimah, S. (2015). Seleksi Pemain Bulu Tangkis Menggunakan Metode Weighted Product. 4(3), 837-844.
Paramita, A., Mustika, F. A., \& Farkhatin, N. (2017). Aplikasi Sistem Pendukung Keputusan Guru Terbaik Berdasarkan Kinerja dengan Metode Analytical Hierarchy Process (AHP). Jurnal Nasional Teknologi Dan Sistem Informasi, $3(1)$,

9-18. https://doi.org/10.25077/teknosi.v3i1.2017.918

Saefudin, \& Wahyuningsih, S. (2014). Sistem Pendukung Keputusan Untuk Penilaian Kinerja Pegawai Menggunakan Metode Analytical Hierarchy Process (Ahp) Pada RSUD Serang. Jurnal Sistem Informasi, 1(1), 33-37. Retrieved from http://digilib.uinsuka.ac.id/7334/2/BAB I, VII, DAFTAR PUSTAKA.pdf 